\title{
Choledochocele に対する内視鏡的乳頭括約筋切開術の長期予後の検討
}

\author{
佐田厚生会佐田病院外科, 九州大学大学院臨床 - 腫瘍外科* \\ 小田斉中村光成植木敏幸佐田正之 \\ 大塚隆 生”川本雅彦*田中雅 夫*
}

先天性胆道㹡張症のなかでも極めて稀とされる choledochocele に対する内視鏡的乳 頭括約筋切開術(EST)の長期予後を検討した，対象は男性 2 例，女性 3 例で年齢63〜96

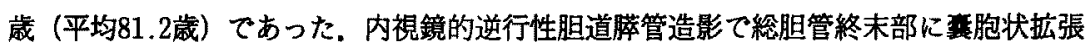
を認め, 本症と診断された. 全例が胆管炎症状を呈しており, 胆汁うっ滞の解除を目的 に EST を施行した。 96歳の男性例は診断時にすてに乳頭部癌を合併しており，内視鏡的 ステント挿入術を行ったが14カ月後に癌死した。他の 4 例は EST 後に顀胞は速やかに 消失し，35〜110力月 (平均64.6力月) の観察期間で胆管炎や膵炎症状はなく, 長期予後

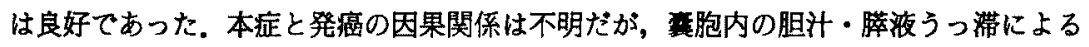
癌化機序が推察される.ESTでうっ滞を解除すれば虞化のリスクは隇少し, 外科的暴胞 切除は不要と考えられる.しかし,EST 後も発癌の可能性を完全には否定できないため, 䇴重な経過観察は必要である。

真引用語 : choledochocele, 内視鏡的乳頭括約筋切開術, 胆道拡張症, 胆汁うっ滞, 癌 化

\section{緒言}

先天性胆道拡張症のなかでも極めて稀とされる choledochocele は Alonso-Lej UI型"に分類され，十 二指腸壁内の総胆管終末部の重胞状拡張を特徵とす る. 発症年龄が高く膵胆管合流異常2》を有しないなど, 他の胆道拡張症とは明らかに異なる病態を示す 症の初期治療は，亯胞内の胆汁うっ滞を解除する目的 て内視鏡的乳頭括約筋切開術 (EST) が推罂されてい る4).しかし，今までに EST 後に長期観察した報告は なく、癌化や予後については明らかにされていない。 そこで当院において EST を施行した choledochocele の長期予後を検討した。

\section{対象および結果}

当院において1993年から2001年までの 9 年間に内視 鏡的逆行性胆道膆管造影 (ERCP) を1,231例に施行し， うち 5 例が choledochocele と診断された. Table 1 に 臨床像を要約した。男性 2 例，女性 3 例で診断時の年

2002年10月23日受付 2003 年 2 月17日採用 〈所属施設住所〉

\%810-0004 福岡市中央区渡辺通 2-4-28
齢は63〜96歳（平均81.2歳）であった。いずれの症例 も発熱, 右上腹部痛などの胆管炎症状が初発症状て,

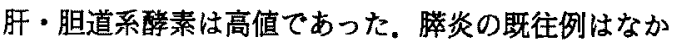
った. ERCP 時の内視鏡像で十二指腸壁内の総胆管終

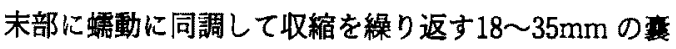
胞状搪張を認め本症と診断された（Fig. 1a, b). 症例 2 の ERCP で，十二指腸壁内の総胆管終末部に算胞 状に搪張した cele が造影された後, cele に開口してい る総胆管と膵管が同時に造影された (Fig. 2). 他の 4 例の ERCP では，共通管は短く，脺管と胆管は選択的 に造影された。膵管造影では正常な豚管のみが描出さ れ，cele は造影されなかった (Fig. 3a)，胆管造影で は総胆管終末部に cele が確認され, cele と膵管に直接 の交通は認めなかった (Fig. 3b). 症例 3 の総胆管は $21 \mathrm{~mm}$ と頭嗹状に抎張していた。他の 4 例の総胆管径 は10〜13mm と正常もしくは軽度㹡張であった．胆汁 アミラーゼを測定した 2 例はいずれも高值を示した。

壤胞粘膜の生検は 2 例に行われ病理組織学的診断はお のおの胆管上皮と十二指腸粘膜であった. 全例に EST を施行し萁胞を十分に開放した（Fig. 4a)，1週間目

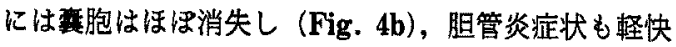


Table 1 Five patients with choledochocele

\begin{tabular}{|c|c|c|c|c|c|c|c|c|c|}
\hline No. & $\begin{array}{l}\text { Age } \\
\text { Sex }\end{array}$ & Symptoms & Type & $\begin{array}{l}\text { Cele size } \\
(\mathrm{mm})\end{array}$ & Stones & Therapy & $\begin{array}{c}\text { Follow-up } \\
\text { (month) }\end{array}$ & Prognosis & Remarks \\
\hline 1. & $\begin{array}{l}63 \\
F\end{array}$ & $\begin{array}{c}\text { Fever } \\
\text { Abdominal pain }\end{array}$ & $\begin{array}{c}\text { KagiyamaD } \\
\text { Ohtsuka } 2\end{array}$ & $18 \times 15$ & $\begin{array}{c}\text { GB } \\
\text { (Choresterol) }\end{array}$ & $\begin{array}{l}\text { EST } \\
\text { LSC }\end{array}$ & 110 & Good & $\begin{array}{l}\text { Early gastric } \\
\text { cancer }\end{array}$ \\
\hline 2. & $\begin{array}{l}82 \\
\mathrm{M}\end{array}$ & $\begin{array}{c}\text { Fever } \\
\text { Vomiting }\end{array}$ & $\begin{array}{c}\text { KagiyamaD } \\
\text { Ohtsuka } 1\end{array}$ & $35 \times 27$ & $\begin{array}{c}\text { GB } \\
\text { (Cholesterol) }\end{array}$ & $\begin{array}{l}\text { EST } \\
\text { LSC }\end{array}$ & 88 & Good & $\begin{array}{l}\text { Bile amylase: } \\
221,875 \mathrm{IU} / \mathrm{L}\end{array}$ \\
\hline 3. & $\begin{array}{l}84 \\
F\end{array}$ & Abdominal pain & $\begin{array}{c}\text { KagiyamaD } \\
\text { Ohtsuka } 2\end{array}$ & $22 \times 20$ & $\begin{array}{l}\mathrm{GB} \cdot \mathrm{CBD} \\
\text { (Bilirubin) }\end{array}$ & $\begin{array}{l}\text { EST } \\
\text { LSC }\end{array}$ & 54 & Good & $\begin{array}{c}\text { Choledochal } \\
\text { cyst }\end{array}$ \\
\hline 4. & $\begin{array}{l}96 \\
M\end{array}$ & $\begin{array}{c}\text { Icterus } \\
\text { Abdominal pain }\end{array}$ & $\begin{array}{c}\text { KagiyamaD } \\
\text { Ohtsuka } 2\end{array}$ & $18 \times 13$ & None & $\begin{array}{l}\text { EST } \\
\text { Stent }\end{array}$ & 36 & Dead & $\begin{array}{l}\text { Ampullary } \\
\text { cancer }\end{array}$ \\
\hline 5. & $\begin{array}{l}81 \\
F\end{array}$ & $\begin{array}{l}\text { Abdominal pain } \\
\text { Vomiting }\end{array}$ & $\begin{array}{c}\text { KagiyamaD } \\
\text { Ohtsuka } 2\end{array}$ & $21 \times 14$ & $\begin{array}{l}\mathrm{GB} \cdot \mathrm{CBD} \\
\text { (Bilirubin) }\end{array}$ & $\begin{array}{l}\text { EST } \\
\text { LSC }\end{array}$ & 35 & Good & $\begin{array}{l}\text { Bile amylase: } \\
7,290 \mathrm{IU} / \mathrm{L}\end{array}$ \\
\hline
\end{tabular}

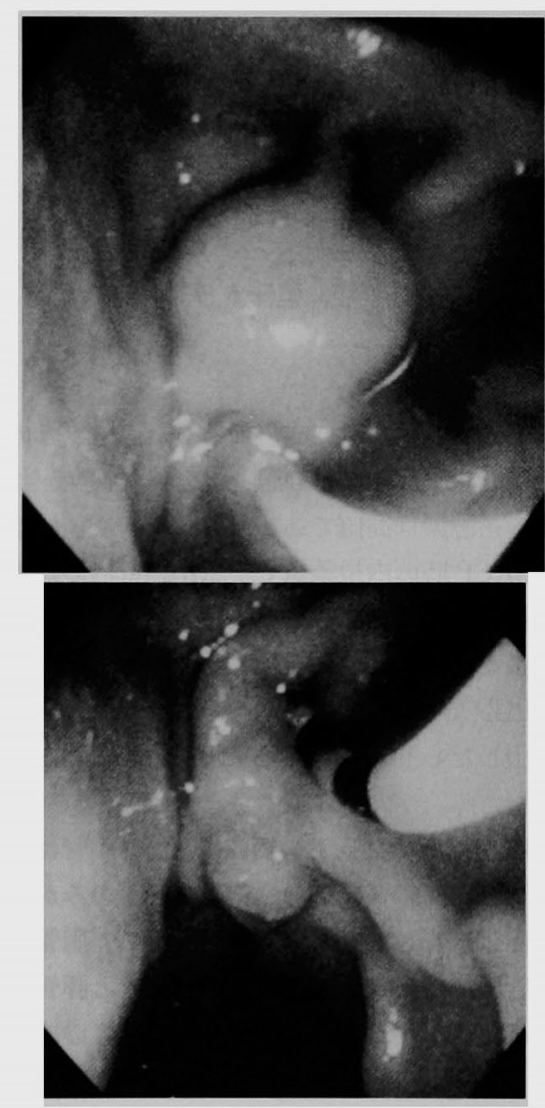

Fig. 1: a) Duodenoscopy shows a smoothsurfaced hemispherical swelling at the oral side of the ampullary orifice (case 1).

b) The swelling is dented easily, enabling us to distinguish the choledochocele from a submucosal tumor.

$\frac{a}{b}$

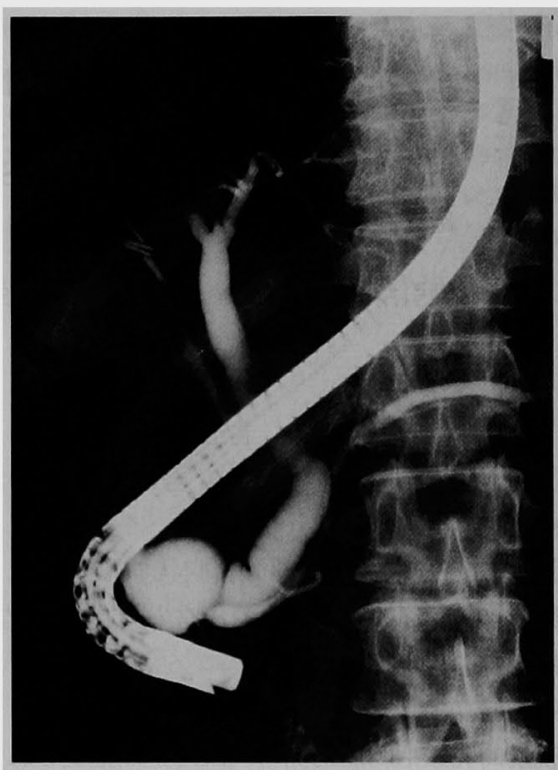

Fig. 2: Endoscopic retrograde cholangiopancreatography reveals cystic dilatation of the distal common bile duct (case 2). The contrast medium enters into the cele and then both into the bile and pancreatic ducts simultaneously (case 2). The common bile and pancreatic ducts open separately in the cele.

した. 4 例に䏣蕉結石，うち 2 例に総胆管結石を合併 していた．総胆管結石 2 例は EST 後に内視鏡的に切 石し，胆趸結石例はすへて腹腔鏡下胆蓄摘出術を施行 した. 赤外線による化学分析により，コレステロール 石 2 例，ビリルピンカルシウム石 2 例であった. 症例 

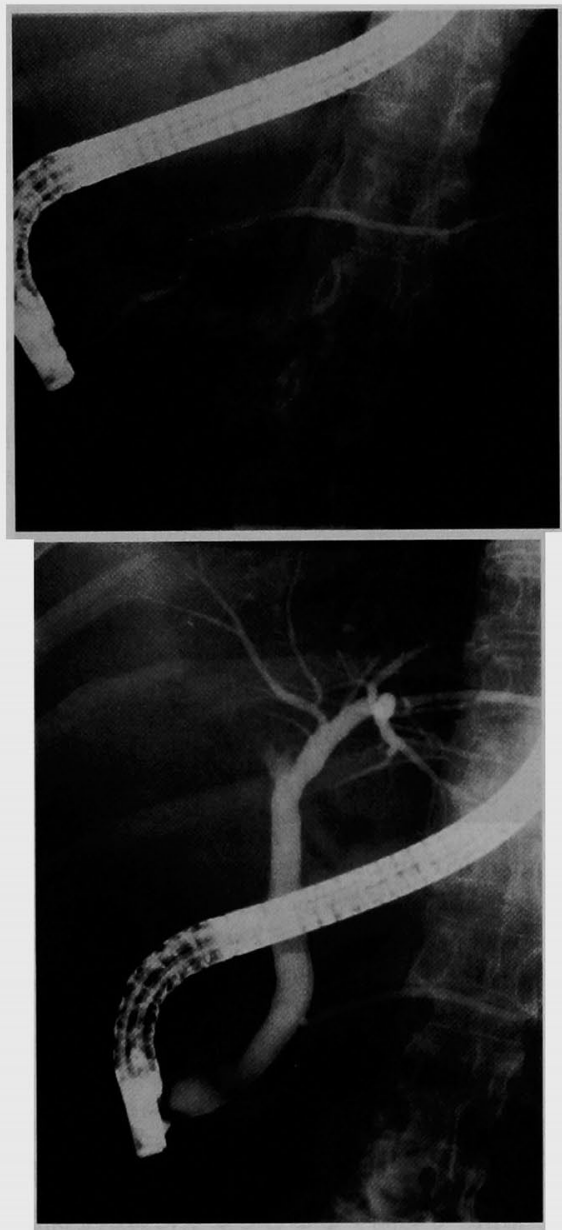

Fig. 3 : Selective cannulation both into the bile and pancreatic ducts is performed (case 1). a) The pancreatic duct is depicted normally but the cele is not visualized. b) Cystic dilatation of the distal common bile duct is shown. The cele is independent of the pancreatic duct.

4 は初回 ERCP 時に乳頭部が易出血性で発赤顆粒状 を呈し，生検で乳頭部癌と診断された（Fig. 5a).96 歳と高龄であったことから根治手術は施行せず, EST で留胞を開放した後に胆管炎症状が軽快したため退院 した，黄㾝が出現し始めた 9 力月目に再入院し内視鏡 的ステント挿入術を行ったが (Fig. 5b)，14力月後に 癌死した。他の 4 例は35〜110力月（平均64.6力月）の 観察期間で胆管炎や膵炎症状もなく経過良好である. 全症例に対して血液生化学検査, 腹部超音波検查, 腹

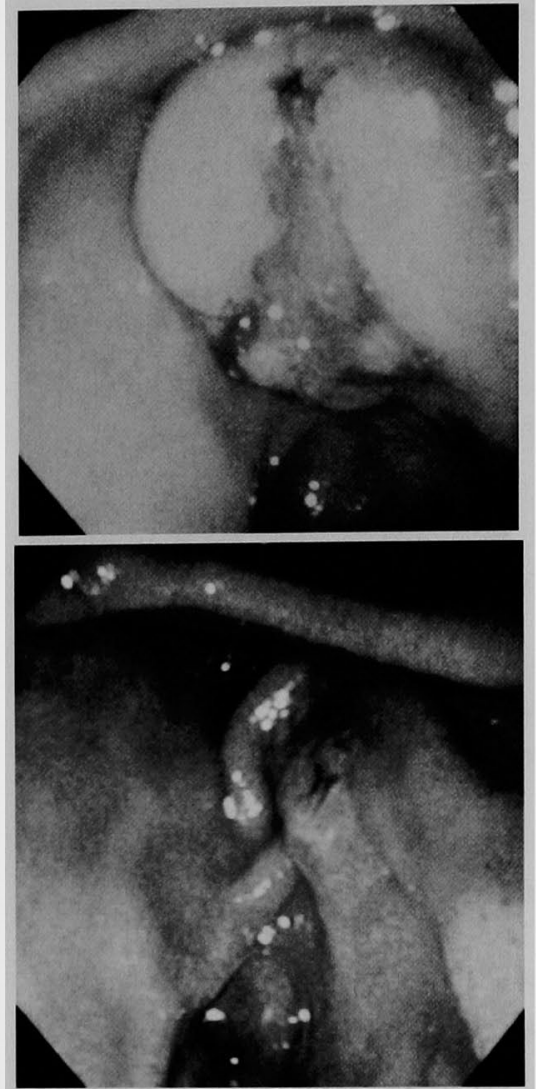

Fig. $4:$ a) The cele is fully opened by endoscopic sphincterotomy (case 1). b) In a week, the cele has already disappeared and bile and pancreatic juice flow out from the respective orifice.

$\frac{a}{b}$

部 CT, ERCP (Fig. 6) などを定期的に行い厳重な経 過観察をしている. EST 後も総胆管径に変化はない. 症例 1 は経過中 7 年目に早期胃癌を発症し胃切除術を 行った. 症例 3 は高龄のため総胆管暴腫に対する胆管 切除・胆道再建術は行っていないが悪性病変の発生は ない.

\section{考察}

本症は先天性胆道拡張症なかでも極めて稀な疾患で あるが, ERCPや magnetic resonance cholangiopancreatography ${ }^{5}$ など最近の画像診断の進歩により 報告例が徐々に増加している，今までに本邦報告例は およそ80例あった ${ }^{6) 7)}$. 本症は発症年齢が高く，先天性 のほか後天性の要因も示唆されるが8)，その発生機序 は明らかにされていない。 

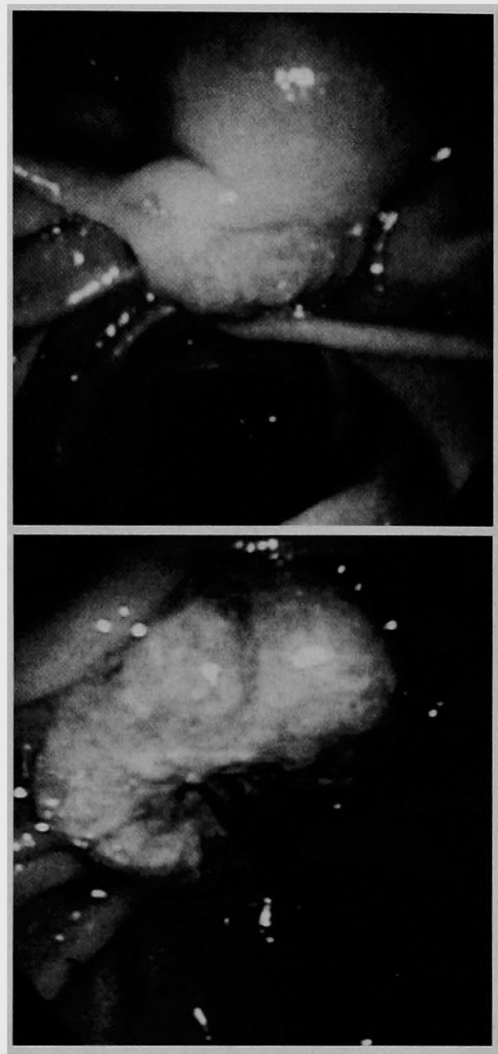

Fig. 5 : a) Duodenoscopy demonstrates the duodenal papilla with a granular and slightly reddish surface (case 4). b) Nine months later, a protruding tumor has grown up to occupy the ampulla and the cele. A stent tube is inserted into the common bile duct through the orifice to relieve obstructive jaundice.

$\frac{\mathrm{a}}{\mathrm{b}}$

Kagiyama $~^{8)}$ は蜼胞開口部と Vater 乳頭の位置関 係や膵胆管合流形式により Scholz らのの分類をもと に本症を 5 型に分類している.

Ohtsuka らフは脺管が基胞内に開口し共通管部分も 拡張しているものを 1 型, 膆管が隻胞外に開口して短 い共通管を形成しているものを 2 型に分類している. 分類に関する詳細はここでは割愛するが，自験例の 5 例はすべて Kagiyama D 型に相当し, 症例 2 は Ohtsuka 1 型, それ以外の 4 例は Ohtsuka 2 型であった.

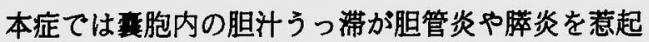
するため, 非手術的に堡胞を開放する ESTがまず選

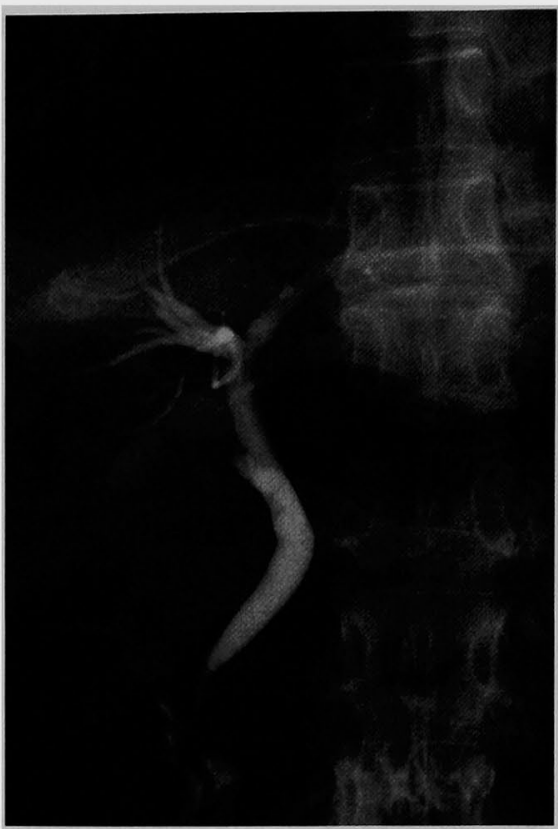

Fig. 6: No abnormal findings of the biliary tree are obtained by endoscopic retrograde cholangiography at a 5-year follow-up period after endoscopic sphincterotomy (case 1).

択されるべき治療法と思われる4).Vater 乳頭または 毫胞の開口部が明らかでない場合は亮胞正中部を needle knife で切開することで安全に旁胞を開放でき る. EST 後に豪胞は速やかに消失し，長期にわたる観 察でも胆管炎や膆炎の再発はなく良好な経過であっ た.

先天性胆道拡張症では胆道癌の発生頻度が極めて高 いことが知られている ${ }^{10) 111}$. 一方, 脺胆管合流異常を有 しない choledochocele と発癌との関連はいまだ確立

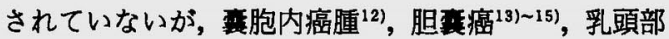
癌16177)などの合併例が散見される。本症の形態上の特 徵から，囊胞内に胆汁と脺液がうっ滞し細胞障害性の ある lysolecithinなどが産生され ${ }^{18)}$ ，ついには赛胞内 癌や自験例のごとき乳頭部癌の発生に至ることが推察 される，逆に本症で癌発生の報告が少ない事実はう つ滞による刺激期間が比較的短いことを示唆し，後天 性発生説を支持している.EST 前に胆汁中アミラーゼ を測定した自験例 2 例はいずれも高值で脺液の逆流， うっ滞が示された。 とくに膵管が蓑胞内に開口してい る Ohtsuka 1 型はより癌化のリスクが高いことが予 
想される，胆汁と膵液のうっ滞をできるだけ早期に解 除すれば癌化のリスクは滅少するであるう.ESTで罴 胞を十分に開放しうっ滞を解除できれ代，開腹下での 賴胞切除は必要ないと考えている。しかし，それまで の慢性的刺激がすで癌化を誘導している可能性は否 定できず, EST 後も少なくとも数年間は乳頭部の内視 鏡下の経過観察・生検が必要と思われる. EST の切開 口から胆管粘膜生検も可能でありこのの点でも EST による治療は有利である. 初回 ERCP 時にすでに乳頭 部癌を合併していた 1 例を除いて, 自駼例 4 例は EST 治療後最長 9 年間て胆道癌の発生はない。 また, 今ま でに胆道以外の他藏器癌合併の報告はないが，自験例 の胃癌発生注 EST 後 7 年を経過しており偶発的なも のと思われる。

\section{結 語}

本症に対するEST の長期予後は良好であり外科的 裹胞切除は不要と考えられた。 しかし, 発癌との関連 性は否定できないため, EST 治療後も厳重な経過観察 は必要である。

本論文の要旨仙第55回日本消化器外科学会総会 (平成 12 年7月，営崎）において発表した。

$$
\text { 文献 }
$$

1) Alonso-Lej F, Rever WB Jr, Pessagno DJ, et al : Congenital choledochal cyst, with a report of 2 , and an analysis of 94 , cases. Int Abstr Surg $108: 1-30,1959$

2）戸谷拓二，渡辺菉宏，土枝 彰他：膵・胆管合流 異常の形態と定義一䐁・胆管合流異常研究会・診 断基準委員会の定義一。胆と滕 $17: 693-696$, 1996

3）戸谷拓二：先天性胆道㹡張症の定義と分類. 胆と 茦 $16: 715-717,1995$

4）田中雅夫，松本伸二，吉本英夫他：内視鏡的乳頭 括約筋切開術によって治療し得た choledochocele の 1 例. 肝・胆・脺 $6: 771-774,1983$

5）伊藤高広，廣橋伸治，打田日出夫他：MRCP(MR cholangio-pancreatography）が診断に有用であ った choledochocele の 1 例。胆と勝 $18: 951$ 956, 1997

6) Yamaoka $K$, Tazawa J, Koizumi $K$, et al: Choledochocele with obstructive jaundice: $\mathrm{A}$ case report and a review of the Japanese litera. ture. J Gastroenterol 29:661-664, 1994

7) Ohtsuka $T$, Ohuchida $J$, Inoue $K$, et al : Car- cinoma arising in choledochocele. Endoscopy $33: 614-619,2001$

8) Kagiyama S, Okazaki $K$, Yamamoto $Y$, et al: Anatomic variants of choledochocele and manometric measurements of pressure in the cele and orifice zone. Am J Gastroenterol 82 : 641-649, 1987

9) Scholz FJ, Carrera GF, Larsen CR: The choledachocele: Correlation of radiological, clinical and pathological findings. Radiology $118: 25-28,1976$

10) Todani $T$, Tabuchi $K$, Watanabe $Y$, et al: Carcinoma arising in the wall of congenital bile duct cysts. Cancer 44 : 1134-1141, 1979

11) Chijiiwa $K$, Kimura $H$, Tanaka $M$ : Malignant potential of the gallbladder in patients with anomalous pancreaticobiliary ductal junction. Int Surg 80:61-64, 1995

12) Ozawa $K$, Yamada $T$, Matumoto $Y$, et al: Carcinoma arising in a choledochocele. Cancer $45: 195-197,1980$

13）三井 媇, 佐々木正寿, 浅田康行他：合流異常, 胆妻癌を合併した choledochocele. 日消病会誌 $83: 136,1986$

14）赢藤祐一郎，林 伸行，小森保生他：胆蕃癌を合 併した choledochocele の I 例. Gastroenterol Endosc $30: 1632,1988$

15）塩見精朗，小林 滋，中川浩之他：胆黄癌を併存 した choledochocele の 1 例. 日消外会誌 22 ： 957-960, 1989

16）中島千春，北川阵夫，津金般俊他：Choledochoceleに癌を合併した極めて稀な症例。胆道 $3: 308,1986$

17) Ladas SD, Katsogridakis I, Tassios $P$, et al: Choledochocele, an overlooked diagnosis: Report of 15 cases and review of 56 published reports from 1984 to 1992 . Endoscopy 27 : 233239, 1995

18) Shimada K, Yanagisawa J, Nakayama $F$ :Increased lysophosphatidylcholine and pancreatic enzyme content in bile of patients with anomalous pancreaticobiliary ductal junction. Hepatology 13 : 438-444, 1991 


\title{
LONG-TERM RESULTS OF ENDOSCOPIC SPHINCTEROTOMY IN PATIENTS WITH CHOLEDOCHOCELE
}

\author{
Hitoshi ODA, Mitsunari NAKAMURA, Toshiyuki UEKI, \\ Masayuki SADA, Takao OHTSUKA*, \\ Masahiko KAWAMOTO* and Masao TANAKA* \\ Department of Surgery, Sada-Koseikai Sada Hospital \\ -Department of Surgery and Oncology, Graduate School of Medical Sciences, Kyushu University
}

We discuss the long-term results of endoscopic sphincterotomy (EST) in patients with choledochocele, a rare congenital biliary dilatation. Subjects were 2 men and 3 women aged 63 to 96 years (mean : 81.2 years) diagnosed by endoscopic retrograde cholangiopancreatography showing cystic dilatation of the terminal common bile duct (CBD). In all with cholangitis, we conducted EST to relieve biliary stagnation. A 96-year-old man with ampullary cancer arising in the cele had an endoprosthesis and died 14 months later. In the other 4, the cele was disappeared and symptoms were ameliorated. They remain alive without cholangitis or pancreatitis during follow-up of 35-110 months (mean:64.6 months). Pancreatobiliary stagnation in the cele may induce malignant changes. Once EST relieves stagnation, the frequency of carcinogenesis is reduced, potentially rendering surgical resection unnecessary. Due to the possibility of malignant changes already induced before EST, however, the ampullary mucosa should be meticulously observed for at least several years even after EST. 